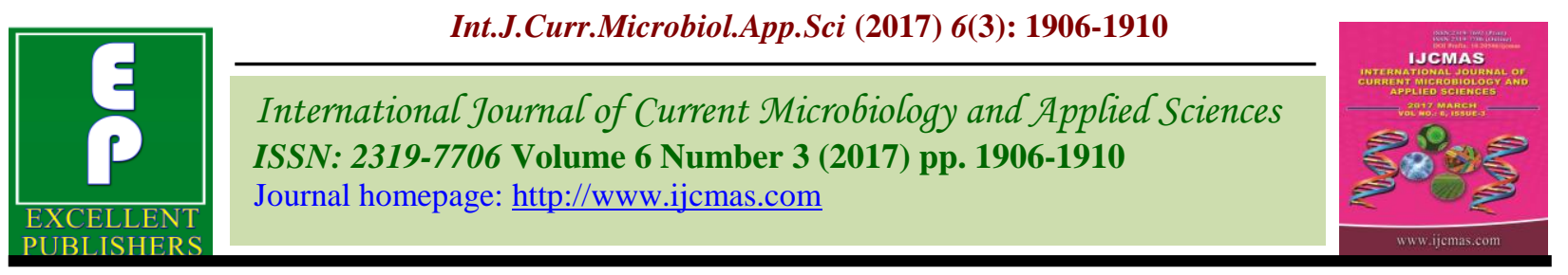

Original Research Article

https://doi.org/10.20546/ijcmas.2017.603.216

\title{
Checklist of Birds Diversity of Madhavrao Patil College Campus Palam District, Prbhani, Maharashtra, India
}

\author{
Varsha Dabhade* and S.V. Poul \\ Madhavrao Patil Arts, Commerce and Science, Palam District, Parbhani, \\ Maharashtra, India 431720 \\ *Corresponding author
}

\begin{tabular}{|c|c|}
\hline & A B S T R A C T \\
\hline Keywords & \\
\hline $\begin{array}{l}\text { Madhavrao Patil } \\
\text { College, Checklist of } \\
\text { birds diversity. }\end{array}$ & \multirow{3}{*}{$\begin{array}{l}\text { Madhavrao Patil College is located outside } 2 \mathrm{~km} \text { adjoined to Palam city. } \\
\text { This area is almost agrarian area and one water body around college } \\
\text { campus. Abundant birds' species found during November to April and July } \\
\text { to October. During this study, } 45 \text { species of } 26 \text { families of birds were } \\
\text { observed and recorded. }\end{array}$} \\
\hline Article Info & \\
\hline $\begin{array}{l}\text { Accepted: } \\
\text { 24 February } 2017 \\
\text { Available Online: } \\
\text { 10 March } 2017\end{array}$ & \\
\hline
\end{tabular}

\section{Introduction}

Birds are of great economic importance to the human society. They play an important role in controlling population of different insects and pests (Balkhande et al., 2013). Birds potentially detect aspects of any landscape condition that are not detected by the other animal groups commonly used as indicators. They are helpful and help to provide rich food for mankind and are known to man since ages (Chitampally, 1993).

The foundation of economic ornithology which promotes the scientific study of avian species, researcher have studied avian fauna in Marathwada as this area is blessed with various natural habitats such as river, reservoirs, hills, forests, grassland. Yardi et al., (2004) reported 64 species of birds in Salim Ali lake, Aurangabad; Kulkarni et al.,
(2005) reported 151 species of birds in and around Nanded city; (Balkhande et al., 2012) recorded 53 species of birds on river Godavari near Dhangar Takli;

Kulkarni et al., (2006) also recorded 93 species of birds in Shikhachi Wadi, reservoir Dist. Nanded (Balkhande et al., 2012) recorded 50 species of birds near river Purna Dist. Parbhani. Kulkarni et al., (2010) listed 62 bird species in forest Jaldhara, Kinwat. Dist. Nanded.

The college campus is very close $(2 \mathrm{~km})$ to adjoin to the city. In the present investigation, efforts have been made to enlist the avian fauna observed on the college campus revealing the bird diversity. 


\section{Materials and Methods}

The present study is based on observation made from November 2013 to April 2014. Birds were observed all around the college campus (32 hector) and of $2 \mathrm{~km}$ agrarian area around it and one water body in college campus itself. Birds were observed twice a day at morning time and evening time for two-three hours, with daily observation made.

Birds were sighted by using binoculars of $7 \mathrm{X}$ and $8 \mathrm{X}$ magnification and were photographed by using Sony Handicam model No. HDRCX190E and Sony cyber shot model no. W570

Spot identification was done by using field guides (Grimmette et al., 1999, Tiwari, 2005; Ali et al., 2003) and after confirmation of identity those species are reported in this paper. As per the guidelines given in the checklist of birds, given by (Abdulali, 1981; Gaikwad et al., 1997; Kulkarni et al., 2005) then checklist is prepared.

The status of each species is categorized as RC- Resident Common, RM- Resident Migrant, RMC- Resident Migrant Common, Rr-Resident rare, WMU- Winter Migrant Uncommon, BMU- Breeding Migrant Uncommon, and M- Migrant.

\section{Results and Discussion}

According to Borale et al., (1994) and Pawar et al., (2010) birds have been considered as useful biological indicators because they are ecologically versatile and live in all kinds of habitats. They are susceptible to the changes in wetlands or ecosystems, some birds are migratory and are responsible for fluctuation in the population. Fluctuation in population helps to know whether the area is normal or polluted. Total absence of birds from any area may be considered as pollution indication.
The study reveals the occurrence of 45 species of birds belonging to 26 families recorded during this study shown in Table No. 1, which depicts details about the Scientific and Common Names, Status and Occurrence of birds.

Out of 45 species 27 species are of Resident Common (RC), like White Breasted Kingfisher, Pied Kingfisher, Small Blue Kingfisher, Indian Pond Heron, Cattle Erget, Red Vented Bulbul, Common Myna, Jungle Myna, Brahminy Starling, Small Bee Eater, Red Wattled Lapwing, Yellow Wattled Lapwing, Asian Koel, Common Peafowl, Gray Partridge, Blue Rock Pigeon, Eurasian Collared Dove, Spotted Dove, Little Brown Dove, Rose Ringed Parakeet, Purple Rumped Sun Bird, Small Sun Bird, House Sparrow, Indian Roller, House Crow, Tailor Bird, Pied Bush Chat.

Out of 45 species 08 species are Resident Migrant (RM), which are Large Egret, Purple Heron, Goo Sander, Visabelline Chat, White Wagtail, Little Cormorant, Pariah Kite, Indian Reef Heron.

03 species are Residential Migrant Common (RMC), which are Blacked Winged Kite, Red Collared Dove, Common Coucal. 03 Species of Residential rare (Rr), those are Shikra, Purple Sun Bird, Indian Grey Hornbill and 2 species of Breeding migrant Uncommon (BMU) are recorded, those are Black Drongo and Indian Robin.

Only 1 species of Migrant (M) is observed, out of 45 species i.e, Thick Billed Warbler and also only 1 species of Winter Migrant Uncommon (WMU), out of 45 species is observed i.e, Common Sand Warbler. 
Table.1

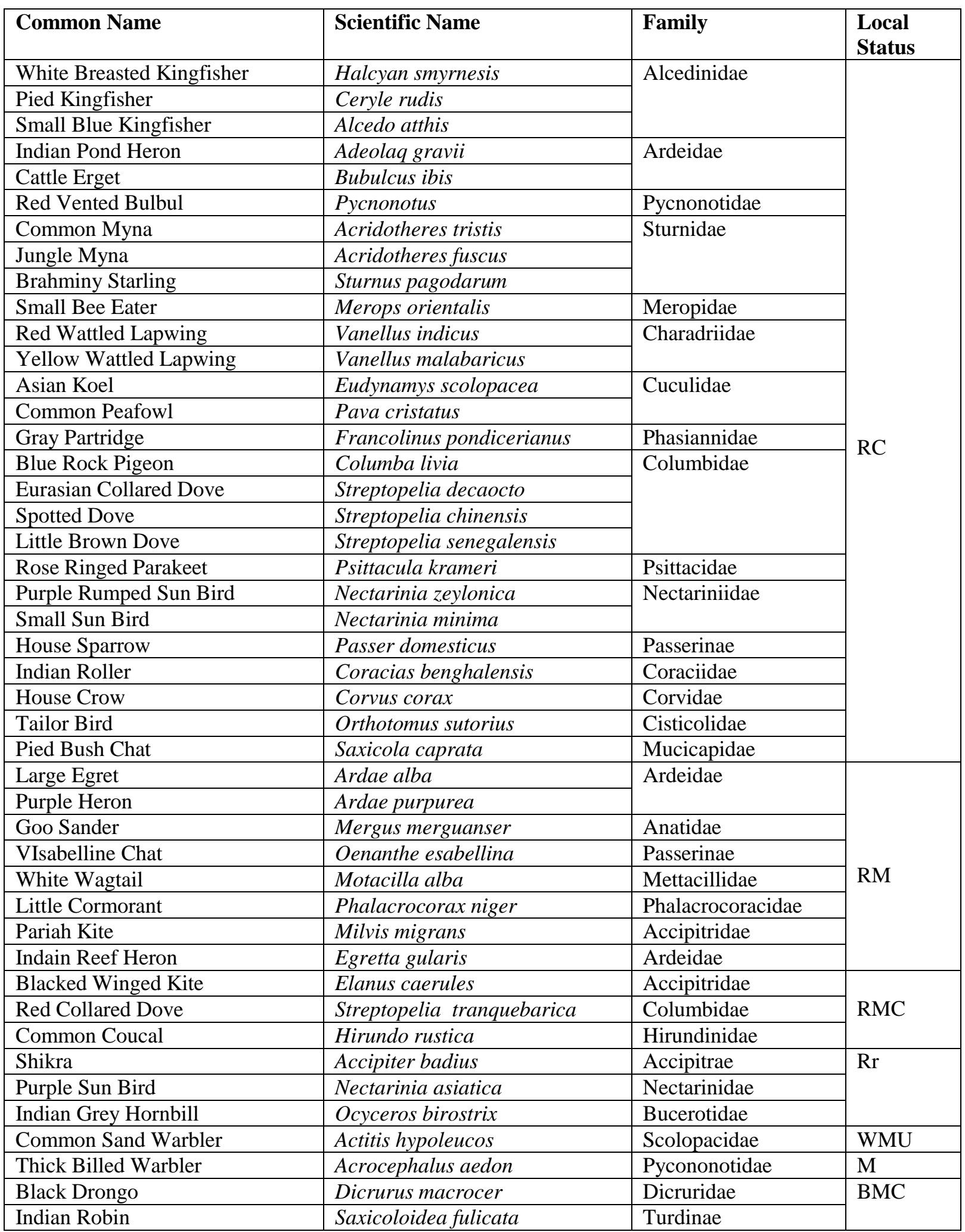

Key to abbreviations: RC- Resident Common, RM- Resident Migrant, RMC- Resident Migrant Common, RrResident rare, WMU- Winter Migrant Uncommon, M- Migrant, BMU- Breeding Migrant Uncommon. 
Similar type of studies was carried out by Kulkarni et al., (2006) recorded 18 Piscivorous bird species in Dongarkheda irrigation tank Dist. Hingoli., Kulkarni et al., (2010) listed 62 bird species in forest Jaldhara, Kinwat Dist. Nanded., Pawar et al., (2010) recorded 95 bird species from three water reservoir from Dist Satara.

In present study, White breasted kingfisher, Pied kingfisher, Indian Pond heron, Large Egret, Red Vented Bulbul, Common Myna, Small Bee Eater, Blue Rock Pigeon, Rose Ringed Parakeet, Cattle Egret, Red Wattled Lapwing, Eurasian Collared Dove and Little Cormorant were found in good numbers.

Madhavrao Patil college campus and surrounding agrarian area has very less human activity at morning and evening and by which, it provides at availability of food, water, climatic conditions and surrounding vegetation of equally favourable for avian fauna. Hence it is a potential site for bird watching.

\section{Acknowledgement}

Author is thankful to her project fellow students and Principal of Madhavrao Patil College, Palam, continuous help and encouragement during study

\section{References}

Abdulali, H. 1981. Checklist of birds of Maharashtra. Bombay Natural History Society, Mumbai, 1-16pp.

Ali, S. 1996. The Book of Indian Birds. BNHS Mumbai, Pp- 1-354.

Ali, S. and Fatehali, L. 2003. Bhartiya Pakshi. National Book Trust, India.

Balkhande, J.V., C.S. Bhowate and A.N. Kulkarni. 2012. Check list of birds of river godavari, dhangar takli near purna, Dist. Parbhani Maharashtra Bionano frontier, Vol. 5(2): 266-268pp

Balkhande, J.V., Wanule D.D., Ratnakar P. U., Shaikh Azeem I. and A.N. Kulkarni. 2013. Avian fauna of Jagtung Sagar, Kandhar Dist. Nanded. M.S.) India. Sci. Res. Rept., 3(2):183-187pp

Balkhande, J.V., Balkhande, S.V., Bhowate, C.S. and Kulkarni, A.N. 2012. "A Check list of Birds near the river Purna, Dist. Parbhani, Maharashtra". Bionotes, 14(4): 110-112.

Borale, R.P., Patil, V. and Vyawahare, P.M. 1994. Study of population of local and migratory birds observed in and around Dhule, M.S, Pavo, 32: 81-86pp.

Chittampalli, M. and B.P.N. Bhatkhande. 1993. Hansdev's Mrigpakeshi Shastra. M.S. Board of literature and culture, Mumbai Pp 1-279.

Gaikwad, N.S., Puranik and M. Shah. 1997. A Check list of Birds around Sholapur. Paper presented in 16th Maharashtra State friends of Birds meets Sholapur. 11 Jan- 1997 1-30pp

Grimmette, K., C. Inskipp and T. Inskipp. 1999. Birds of Indian Sub continent. Oxford University Press, New Delhi, $384 \mathrm{pp}$.

Kulkarni, A.N. and V.S. Kanwate. 2006. Piscivorous birds of Dongarkheda irrigation tank, Dist. Hingoli. Maharashtra. J. Aqua. Biol., 21(1): 8687pp.

Kulkarni, A.N. and V.S. Kanwate. 2010. Avian fauna of forest Jaldhara, Kinwat Dist. Nanded, Maharashtra. J. Aqua. Biol., 25(1): 46-51pp.

Kulkarni, A.N., V.S. Kanwate \& V.D. Deshpande. 2005. Birds in and around Nanded city, Maharashtra. Zoo's print J., 20(II): 2076-2078pp.

Kulkarni, A.N., V.S. Kanwate \& V.D. Deshpande. 2006. Check list of Birds of Shikhachiwadi Reservoir. Dist. Nanded, Maharashtra. J. Aqua. Biol, 21(10): 8085pp. 
Pawar, S.M., R.M., Ganeshwade \& S.R. Sonwane. 2010. Avifauna along tree water reservoir from Satara District. Maharashtra), India, The Bioscan, 5(4): 609-612pp.

Tiwari, V.M. 2005. "Joy of Bird watching".
National Book Trust, India. 2005. Yardi, D.S., S. Patil, R.G. Auti. 2004. Diversity of avian fauna from st Salim Ali Lake at Aurangabad. Paper presented in 21 meet of bird lovers of Maharashtra held at Nanded.

\section{How to cite this article:}

Varsha Dabhade and Poul, S.V. 2017. Checklist of Birds Diversity of Madhavrao Patil College Campus Palam District, Prbhani, Maharashtra. Int.J.Curr.Microbiol.App.Sci. 6(3): 1906-1910. doi: https://doi.org/10.20546/ijcmas.2017.603.216 